\title{
Uji Efikasi Ekstrak Tanaman Serai (Cymbopogon citratus) terhadap Tingkat Mortalitas Larva Nyamuk Aedes sp.
}

\author{
Sonnia J. Giroth, ${ }^{1}$ Janno B. B. Bernadus, ${ }^{2}$ Angle M. H. Sorisi ${ }^{2}$
}

\author{
${ }^{1}$ Program Studi Pendidikan Dokter Fakultas Kedokteran Universitas Sam Ratulangi, \\ Manado, Indonesia \\ ${ }^{2}$ Bagian Parasitologi Fakultas Kesehatan Masyarakat Universitas Sam Ratulangi, Manado, \\ Indonesia \\ Email: sonniajgiroth@gmail.com
}

\begin{abstract}
Aedes aegypti and Aedes albopictus are known as the two main vectors of DHF disease. One way to control DHF is by breaking the chain of spread in the larval phase with larvicides. The use of organic larvicides derived from plants is in great demand, one of which is extracts of lemongrass (Cymbopogon citratus). This study aims to determine the level of efficacy or the effect of concentration of lemongrass extract solution on mortality rates of Aedes $s p$. larvae. This is an experimental study using 40 instar larvae III / IV of Aedes $s p$. which were given the intervention of lemongrass plant extracts with a concentration of $5 \%$, $10 \%, 15 \%$, and $20 \%$. This experiment was carried out twice. Four observations were made every 6 hours. Probit analysis was performed to determine Lethal Concentration $\left(\mathrm{LC}_{50}\right.$ and $\mathrm{LC}_{90}$ ) and Lethal Time ( $\mathrm{LT}_{50}$ and $\left.\mathrm{LT}_{90}\right)$. The analysis showed that the lemongrass plant extract at a concentration of $20 \%$ had a significant difference with the concentration of $5 \%, 10 \%$, $15 \%$, and the control group ( $\mathrm{p}<0.05$ ). In conclusion, extract of lemongrass (Cymbopogon citratus) with a concentration of $20 \%$ is effective for killing larvae of Aedes $s p$.
\end{abstract}

Keywords: Aedes sp., Cymbopogon citratus, larval mortality

\begin{abstract}
Abstrak: Nyamuk Aedes aegypti dan Aedes albopictus diketahui sebagai dua vektor utama dari penyakit DBD. Salah satu cara pengendalian DBD adalah dengan memutus rantai penyebaran pada fase larva dengan larvasida. Pemanfaatan larvasida organik atau alami yang berasal dari tumbuh-tumbuhan banyak diminati, salah satunya adalah ekstrak tanaman serai (Cymbopogon citratus). Penelitian ini bertujuan mengetahui tingkat keampuhan atau pengaruh konsentrasi larutan ekstrak tanaman serai terhadap tingkat mortalitas larva nyamuk Aedes $s p$. Penelitian ini bersifat eksperimental sederhana menggunakan 40 ekor larva instar III/IV nyamuk Aedes sp. yang diberikan intervensi ekstrak tanaman serai dengan konsentrasi $5 \%$, $10 \%, 15 \%$, dan 20\%. Pengamatan dilakukan setiap 6 jam sebanyak 4 kali, dengan 2 kali percobaan. Analisis probit dilakukan untuk mengetahui Lethal Concentration $\left(\mathrm{LC}_{50}\right.$ dan $\left.\mathrm{LC}_{90}\right)$ dan Lethal Time ( $\mathrm{LT}_{50}$ dan $\mathrm{LT}_{90}$ ). Hasil analisis menunjukkan bahwa ekstrak tanaman serai pada konsentrasi $20 \%$ memiliki perbedaan signifikan dengan konsentrasi 5\%, 10\%, 15\%, dan kelompok kontrol $(p<0,05)$. Simpulan penelitian ialah ekstrak tanaman serai dengan konsentrasi $20 \%$ efektif untuk mematikan larva Aedes sp.
\end{abstract}

Kata Kunci: Aedes sp., Cymbopogon citratus, mortalitas larva

\section{PENDAHULUAN}

Nyamuk Aedes aegypti dan nyamuk Aedes albopictus diketahui sebagai dua vektor utama dari beberapa arbovirus, yang mana nyamuk Aedes aegypti sebagai vektor utama dan nyamuk Aedes albopictus sebagai vektor potensial. ${ }^{1}$ Nyamuk Aedes aegypti tersebar di seluruh negara tropis dan subtropis terlebih khusus di wilayah Asia Tenggara. ${ }^{2}$ Nyamuk Aedes albopictus pertama kali dikenalkan oleh Skuse (1894), termasuk subgenus Stegomya dan merupa- 
kan spesies penting selain Aedes aegypti. Secara morfologi, nyamuk Aedes aegypti dan Aedes albopictus sangat mirip, namun dibedakan dari strip putih yang terdapat pada bagian mesontum. Mesontum Aedes aegypti berwarna hitam dengan dua garis sejajar di bagian dorsal tengah diapit oleh dua garis seperti lyre dengan dua dua garis lurus putih dan dua garis lengkung. Sedangkan mesontum nyamuk Aedes albopictus hanya berisi satu garis putih tebal pada bagian dorsalnya. ${ }^{3}$ Siklus utama nyamuk Aedes aegypti dan Aedes albopictus terdiri dari stadium telur, larva, pupa, dan nyamuk dewasa. Pertumbuhan dan perkembangan nyamuk itu sendiri dipengaruhi oleh beberapa faktor seperti suhu, kelembaban, dan nutrisi. ${ }^{4}$ Umur nyamuk tidak sama. Pada umumnya nyamuk betina lebih lama dari nyamuk jantan. Nyamuk Aedes aegypti merupakan hospes antropofilik, menggigit untuk mencari makanan darah manusia di siang hari. ${ }^{2,5}$ Nyamuk Aedes albopictus mencari darah sepanjang hari, dengan aktifitas menggigit pada sore hari lebih tinggi daripada siang hari. ${ }^{6}$

Faktor-faktor penularan penyakit DBD yaitu agen, penyebar (vector), pejamu (host), dan lingkungan. Faktor agen disebabkan oleh virus dengue (genus flavivirus, family flaviridae). Dengan empat serotipe yaitu DENV 1-4. ${ }^{7}$ Faktor penyebar (vektor): Nyamuk Aedes aegypti dan Aedes albopictus adalah dua vektor utama yang berperan dalam terjadinya demam dengue dan DBD. ${ }^{8}$ Faktor pejamu (host): Penyebaran infeksi terjadi melalui pergerakan inang (manusia) karena pergerakan vektor sangat terbatas. Kerentanan manusia tergantung pada status kekebalan dan kecenderungan genetik. ${ }^{2}$ Faktor Lingkungan: Nyamuk ini telah beradaptasi dengan lingkungan perkotaan, walaupun suhu penting dalam penularan. Aedes aegypti hidup di daerah beriklim tropis, subtropis, dan beberapa iklim sedang, serta merupakan vektor utama penyebaran DBD, zika, dan chikungunya. Nyamuk Aedes aegypti berada disekitar manusia dan memperoleh makanan dari manusia membuat nyamuk lebih mungkin menyebarkan virus ini.
Nyamuk menggunakan wadah buatan untuk tempat perkembangbiakan larva. ${ }^{9}$ Pengendalian vektor Nyamuk Aedes sp. digolongkan dalam pengendalian alami (natural control) dan pengendalian buatan $\left(\right.$ artificial $=$ applied control).$^{5}$

Salah satu cara pengendalian terhadap penyakit DBD adalah dengan menggunakan bahan yang mengandung senyawa kimia yang disebut sebagai insektisida. Adapun pemutusan rantai penyebaran vektor dapat dilakukan pada fase larva atau yang disebut sebagai larvasida. ${ }^{5}$ Namun, penggunaan insektisida memiliki sejumlah efek samping. Berdasarkan penelitian di Mumbai India tahun 2019, penggunaan insektisida sintetis dalam jangka panjang telah membuat nyamuk kebal, sehingga diperlukan metode pengendalian vektor yang baru. ${ }^{10}$ Dalam upaya untuk mengurangi efek samping dari penggunaan insektisida kimia untuk membunuh stadium larva, diperlukan alternatif lain yang lebih aman dan ekonomis serta tidak menimbulkan dampak negatif terhadap lingkungan dan manusia. Salah satu upaya untuk mengurangi dampak negatif ini adalah pemanfaatan insektisida organik yang menggunakan senyawa alami atau berasal dari tumbuh-tumbuhan, seperti halnya penggunaaan ekstrak tanaman serai (Cymbopogon citratus) yang bersumber dari tumbuhan, sebagai inovasi insektisida alami organik yang keampuhannya telah diteliti oleh karena adanya beberapa kandungan bahan aktif. ${ }^{11-13}$

Secara umum tanaman serai dibagi menjadi dua jenis, yaitu serai wangi (Cymbopogon nardus L) dan (Cymbopogon citratus). Secara morfologi, tanaman serai wangi (Cymbopogon nardus L) diketahui memiliki daun memanjang seperti pita semakin ke ujung semakin meruncing, berdaun agak kaku dan berwarna hijau pada bagian pinggir, daun berwarna merah atau ungu. Morfologi serai dapur (Cymbopogon citratus) yaitu berdaun memanjang seperti pita, makin keujung makin meruncing dan warna daun hijau. ${ }^{14}$ Tanaman serai sering dimanfaatkan sebagai bahan makanan seperti bahan sup, salad, 
dan bahan minuman, manfaat lain juga yaitu sebagai anti inflamasi, antiseptik, antiemetik, antirematik, analgesik, antispasmodik, dan antipiretik. ${ }^{15,16}$ Tumbuhan serai dapur (Cymbopogon citratus) yang mengandung bahan aktif yaitu minyak atsiri, seperti sitronelal, sitronelol,dan geraniol. Apabila senyawa-senyawa tersebut dikonsumsi oleh larva, maka organ pencernaan larva akan menghambat reseptor pengecap yang berada pada bagian mulut larva. Hal itu mengakibatkan larva gagal mendapatkan stimulasi rasa, sehingga larva tidak mampu untuk mengenali makanannya dan mengakibatkan larva mati. ${ }^{17,12}$ Tanaman ini juga mengandung bahan aktif seperti flavonoid, saponin dan tannin yang bersifat racun terhadap larva. ${ }^{18}$

\section{METODE PENELITIAN}

Penelitian ini merupakan penelitian eksperimental sederhana. Dilakukan dalam jangka waktu 3 bulan (Oktober - Desember 2020). Penelitian terhadap larva uji dilakukan di Laboratorium Parasitologi Fakultas Kedokteran Universitas Sam Ratulangi Manado. Populasi target yaitu nyamuk Aedes sp. tahap instar III atau IV yang ditangkap oleh peneliti secara acak di tempat penampungan dan wadah terbuka di sekitar wilayah Fakultas Kedokteran Universitas Sam Ratulangi Manado, Kelurahan Malalayang, Kota Manado. Total Sampling (sampel yang memenuhi kriteria inklusi pada pengambilan sampel periode Oktober - Desember 2020). Kriteria inklusi yaitu larva nyamuk Aedes $s p$. tahap instar III atau IV yang hidup dan bergerak aktif. Kriteria ekslusi yaitu bukan larva nyamuk Aedes sp. dan bukan stadium larva Aedes sp. Data disajikan dalam bentuk tabel secara analitik. Untuk mengetahui mortalitas larva, digunakan rumus hitung presentase kematian larva uji sebagai berikut :

Keterangan :

$$
M=\frac{L p-L k}{J L} \times 100 \%
$$

M : Persen mortalitas (kematian larva)

Lp : Jumlah larva yang mati pada kelompok perlakuan

Lk : Jumlah larva yang mati pada kelompok kontrol

JL : Jumlah larva dalam masing-masing beaker
Setelah itu, dilakukan perhitungan data secara statistik menggunakan uji One way Annova jika data berdistribusi normal. Sebelumnya dilakukan uji Saphiro Wilk untuk uji normalitas, lalu dilakukan uji homogenitas dengan Levene's Test. Jika data tidak berdistribusi normal, dilakukan uji alternatif yaitu uji Kruskal Wallis. Selanjutnya uji Post Hoc menggunakan uji Mann Whitney untuk mencari perbedaan rata-rata kematian antar variabel. Digunakan analisis probit untuk mengetahui Lethal Concentration $\left(\mathrm{LC}_{50}\right.$ dan $\mathrm{LC}_{90}$ ) dan Lethal Time $\left(\mathrm{LT}_{50}\right.$ dan $\left.\mathrm{LT}_{90}\right)$.

\section{HASIL PENELITIAN}

Penelitian ini dilakukan di Laboratorium Fakultas Kedokteran Universitas Sam Ratulangi pada bulan Oktober-Desember 2020.

Tabel 1. Persentase kematian larva Aedes $s p$. setelah pemberian beberapa konsentrasi ekstrak tanaman serai (Cymbopogon citratus) setelah 6 Jam

\begin{tabular}{cccccc}
\hline \multirow{3}{*}{$\begin{array}{c}\text { Konsentrasi } \begin{array}{c}\text { Jumlah } \\
(\%)\end{array} \\
\text { Larva }\end{array}$} & $\begin{array}{c}\text { Replikasi } \\
\text { Bahan }\end{array}$ & & \multicolumn{3}{c}{$\begin{array}{c}\text { Kematian } \\
\text { larva setelah 6 } \\
\text { jam perlakuan }\end{array}$} \\
\cline { 3 - 6 } & Uji & I & II & Rerata & $\%$ \\
\hline 5 & 10 & 0 & 1 & 0.5 & 10 \\
10 & 10 & 0 & 1 & 0.5 & 10 \\
15 & 10 & 1 & 2 & 1.5 & 30 \\
20 & 10 & 1 & 4 & 2.5 & 50 \\
Kontrol & 10 & 0 & 0 & 0 & 0 \\
\hline
\end{tabular}

Dari tabel 1 didapatkan bahwa terjadi peningkatan jumlah kematian larva seiring dengan peningkatan konsentrasi perlakuan ditinjau secara kuantitas terhadap setiap kelompok perlakuan.

Tabel 2 menunjukkan bahwa secara kuantitas, dapat dikatakan bahwa pada jam ke 12 terjadi juga peningkatan kematian larva dengan bertambahnya konsentrasi pada setiap perlakuan.

Tabel 3 Terjadi peningkatan jumlah kematian larva seiring dengan peningkatan konsentrasi perlakuan ditinjau secara kuantitas terhadap setiap kelompok perlakuan. 
Tabel 2. Persentase kematian larva Aedes $s p$. setelah pemberian beberapa konsentrasi ekstrak tanaman serai (Cymbopogon citratus) setelah 12 jam

\begin{tabular}{cccccc}
\hline & \multicolumn{3}{c}{ Jumlah } & & \multicolumn{2}{c}{ Kematian larva } \\
Konsentrasi & $\begin{array}{c}\text { Larva } \\
(\%)\end{array}$ & Bahan & Replikasi & \multicolumn{3}{c}{$\begin{array}{c}\text { setelah 12 jam } \\
\text { perlakuan }\end{array}$} \\
\cline { 3 - 6 } & Uji & I & II & Rata-rata & $\%$ \\
\hline 5 & 10 & 0 & 0 & 0 & 0 \\
10 & 10 & 0 & 1 & 0.5 & 10 \\
15 & 10 & 0 & 2 & 1 & 20 \\
20 & 10 & 5 & 2 & 3.5 & 70 \\
Kontrol & 10 & 0 & 0 & 0 & 0 \\
\hline
\end{tabular}

Tabel 3. Persentase kematian larva Aedes $s p$. setelah pemberian beberapa konsentrasi ekstrak tanaman serai (Cymbopogon citratus) Setelah 18 Jam

\begin{tabular}{|c|c|c|c|c|c|}
\hline \multirow[t]{2}{*}{$\begin{array}{c}\text { Konsentrasi } \\
(\%)\end{array}$} & \multirow{2}{*}{$\begin{array}{c}\text { Jumlah } \\
\text { Larva } \\
\text { Bahan } \\
\text { Uji }\end{array}$} & \multicolumn{2}{|c|}{ Replikasi } & \multicolumn{2}{|c|}{$\begin{array}{c}\text { Kematian larva } \\
\text { i setelah } 18 \text { jam } \\
\text { perlakuan }\end{array}$} \\
\hline & & $\mathrm{I}$ & II & Rata-rata & $\%$ \\
\hline 5 & 10 & 0 & 1 & 0.5 & 10 \\
\hline 10 & 10 & 1 & 1 & 1 & 20 \\
\hline 15 & 10 & 0 & 0 & 0 & 0 \\
\hline 20 & 10 & 1 & 3 & 2 & 40 \\
\hline Kontrol & 10 & 0 & 0 & 0 & 0 \\
\hline
\end{tabular}

Tabel 4. Persentase kematian larva Aedes $s p$. setelah pemberian beberapa konsentrasi ekstrak tanaman serai (Cymbopogon citratus) setelah 24 jam

\begin{tabular}{|c|c|c|c|c|c|}
\hline \multirow[t]{2}{*}{$\begin{array}{c}\text { Konsen- } \\
\text { trasi } \\
(\%)\end{array}$} & \multirow[t]{2}{*}{$\begin{array}{l}\text { Jumlah } \\
\text { Larva } \\
\text { Bahan } \\
\text { Uji }\end{array}$} & \multicolumn{2}{|c|}{ Replikasi } & \multicolumn{2}{|c|}{$\begin{array}{c}\text { Kematian } \\
\text { larva setelah } \\
24 \text { jam } \\
\text { perlakuan }\end{array}$} \\
\hline & & I & II & Rata-rata & $\%$ \\
\hline$\overline{5}$ & 10 & 1 & $\overline{0}$ & 0.5 & 10 \\
\hline 10 & & 0 & 1 & 0.5 & 10 \\
\hline 15 & 10 & 1 & 3 & 2 & 40 \\
\hline 20 & 10 & 3 & 3 & 3 & 60 \\
\hline Kontrol & 10 & 0 & 0 & 0 & 0 \\
\hline
\end{tabular}

Tabel 4 menunjukkan bahwa secara kuantitas, terjadi peningkatan jumlah kematian larva pada jam ke-24 seiring dengan peningkatan konsentrasi pada tiap perlakuan.
Uji Analisis data One Way Annova terlebih dahulu dilakukan untuk mengetahui adanya perbedaan rata-rata kematian larva dengan perlakuan berbagai konsentrasi antar kelompok dengan syarat variabel terikat berupa skala numerik, distribusi data normal dan varians sama sebelum dilakukan Analisis Probit, untuk melihat LC. Data terlebih dahulu diuji normalitasnya dengan menggunakan uji Shapiro Wilk karena jumlah sampel $<50$ sebelum dianalisis dengan uji One Way Annova. Uji normalitas digunakan untuk menilai apakah sebaran data yang ada berdistribusi normal. Data dikatakan berdistribusi normal apabila $\mathrm{p}>0.05$. Dari data yang diperoleh dari uji normalitas di atas menunjukkan pada kelompok konsentrasi $5 \%$ dan $10 \%$ memiliki nilai $\mathrm{p}<0.05$ sehingga data pada kelompok konsentrasi $5 \%$ dan $10 \%$ tidak berdistribusi normal, sedangkan pada kelompok konsentrasi $15 \%$ dan $20 \%$ memiliki nilai $\mathrm{p}>0.05$ sehingga data pada kelompok tersebut berdistribusi normal. Kemudian hasil uji homogenitas dengan menggunakan Levene's Test memiliki nilai $\mathrm{p}<0.05$, sehingga data pada semua kelompok penelitian ini memiki varians yang tidak homogen. Berdasarkan data hasil uji normalitas pada dua kelompok konsentrasi tidak berdistribusi normal dan varian data tidak homogen, maka uji One Way Annova tidak dapat dilakukan sehingga dilakukan uji Kruskall Wallis. Kemudian nilai p yang didapat dari uji Kruskall Wallis memiliki nilai p < 0.05, hal ini menyatakan bahwa setelah 24 jam pada berbagai konsentrasi perlakuan terdapat perbedaan tingkat kematian larva Aedes sp. Selanjutnya dilakukan uji Post Hoc untuk mencari adanya perbedaan ratarata kematian larva antar dua kelompok perlakuan, pengujian ini dilakukan menggunakan uji Mann Whitney. Nilai $\mathrm{p}$ dari Mann Whitney yang memiliki nilai $\mathrm{p}<$ 0.05 adalah pada kelompok konsentrasi $5 \%$ dan 20\%, konsentrasi $10 \%$ dan $20 \%$, konsentrasi $10 \%$ dan kontrol, $15 \%$ dan 20\%, 20\% dan kontrol. Dengan demikian dapat dikatan bahwa konsentrasi $20 \%$ memiliki perbedaan signifikan dengan 
konsentrasi $5 \%$ dan $10 \%, 15 \%$ dan kelompok kontrol. Kemudian kelompok kontrol memiliki perbedaan signifikan dengan konsentrasi $10 \%$.

Kemudian dilakukan Analisis Probit dengan tingkat kepercayaan $95 \%$ untuk mendapatkan nilai $\mathrm{LC}_{50}$ dan $\mathrm{LC}_{90}$. Analisis Probit untuk $\mathrm{LC}_{50}$ dan $\mathrm{LC}_{90}$ dapat dilihat pada tabel 5.

Tabel 5. Hasil analisis probit untuk konsentrasi letal

\begin{tabular}{ccc}
\hline $\begin{array}{c}\text { Konsentrasi } \\
\text { letal }\end{array}$ & $\begin{array}{c}\text { Tingkat } \\
\text { Kepercayaan }\end{array}$ & Estimasi \\
\hline 50 & $95.0 \%$ & 11.009 \\
90 & $95.0 \%$ & 22.801 \\
\hline
\end{tabular}

Dari tabel 5, didapatkan untuk hasil Analisis Probit terhadap angka mortalitas larva (Aedes sp.) menunjukkan bahwa konsentrasi $11.01 \%$ dalam waktu 24 jam mampu membunuh 50\% larva. Sedangkan $\mathrm{LC}_{90}$ didapatkan hasil bermakna pada konsentrasi $22.80 \%$ dalam waktu 24 jam mampu membunuh $90 \%$ larva.

Kemudian Analisis Probit untuk $\mathrm{LT}_{50}$ dan $\mathrm{LT}_{90}$ dapat dilihat pada tabel 6 .

Tabel 6. Hasil analisis probit untuk waktu letal

\begin{tabular}{|c|c|c|c|}
\hline Konsentrasi & $\begin{array}{l}\text { Waktu } \\
\text { letal }\end{array}$ & $\begin{array}{c}\text { Tingkat } \\
\text { Kepercayaan }\end{array}$ & Estimasi \\
\hline $5 \%$ & $\begin{array}{l}\mathrm{LT}_{50} \\
\mathrm{LT}_{90}\end{array}$ & $95.0 \%$ & $\begin{array}{l}50.001 \\
92.209\end{array}$ \\
\hline $10 \%$ & $\begin{array}{l}\mathrm{LT}_{50} \\
\mathrm{LT}_{90}\end{array}$ & $95.0 \%$ & $\begin{array}{l}40.431 \\
82.939\end{array}$ \\
\hline $15 \%$ & $\begin{array}{l}\mathrm{LT}_{50} \\
\mathrm{LT}_{90}\end{array}$ & $95.0 \%$ & $\begin{array}{l}27.401 \\
69.609\end{array}$ \\
\hline $20 \%$ & $\begin{array}{l}\mathrm{LT}_{50} \\
\mathrm{LT}_{55} \\
\mathrm{LT}_{90}\end{array}$ & $95.0 \%$ & $\begin{array}{c}-1.639 \\
2.500 \\
40.569\end{array}$ \\
\hline kontrol & $\begin{array}{l}\mathrm{LT}_{50} \\
\mathrm{LT}_{90}\end{array}$ & $95.0 \%$ & $\begin{array}{l}141.489 \\
183.697\end{array}$ \\
\hline
\end{tabular}

Berdasarkan tabel 6, Dapat dilihat bahwa semakin tinggi konsentrasi, nilai LT semakin kecil. Pada konsentrasi 20\% LT $_{50}$ memiliki nilai negatif, dan didapat nilai positif dari $\mathrm{LT}_{55}$.

\section{BAHASAN}

Penelitian ini bertujuan untuk mengetahui tingkat keampuhan atau efektivitas tanaman serai (Cymbopogon citratus) sebagai larvasida alami Aedes sp. dengan menggunakan berbagai kelompok konsentrasi yang berbeda.

Pada penelitian ini dilakukan uji potensi ekstrak tanaman serai (Cymbopogon citratus) sebagai larvasida terhadap larva Aedes sp. dengan berbagai konsentrasi uji. Tanaman Serai dalam penelitian ini merupakan tanaman serai dengan ciri-ciri morfologi yakni berdaun memanjang seperti pita, makin keujung makin meruncing dan warna daun hijau. Tanaman serai yang dipakai berkualitas baik, yang dipotong halus, dikeringkan, dan diblender hingga menjadi halus. Setelah itu, dilarutkan dengan aquades dengan berbagai konsentrasi sebagai larvasida alami. Larva Aedes sp. yang digunakan adalah larva instar III/IV yang hidup dan bergerak aktif. Alasan pemilihan larva tahap instar III/IV dalam penelitian oleh karena larva tahap instar III/IV aktif mengonsumsi makanan di air, serta larva tahap instar III memiliki ketahanan yang lebih baik terhadap faktor mekanis saat terjadi pemindahan tempat dan goncangan tempat, serta larva tahap instar IV memiliki morfologi yang sudah sempurna. ${ }^{19}$ Konsentrasi 5\%, 10\%, 15\%, dan $20 \%$ dipilih sebagai kelompok perlakuan dengan masing-masing perlakuan terdapat 10 ekor larva instar III/IV. Kemudian pengamatan dilakukan setiap 6 jam, 12 jam, 18 jam, dan 24 jam dengan 2 kali percobaan.

Berdasarkan hasil penelitian, didapatkan bahwa pemberian ekstrak tanaman serai mempunyai efek larvisida terhadap Aedes sp. terutama pada konsentrasi $20 \%$ dapat membasmi $70 \%$ larva Aedes sp. pada jam ke-12. Selain itu, didapat hasil uji Kruskall Wallis yang menyatakan bahwa terdapat perbedaan yang bermakna ( $\mathrm{p}<$ 0,05) antara konsentrasi $20 \%$ terhadap semua konsentrasi, hal ini dapat menjadi bukti bahwa semakin tinggi atau meningkatnya konsentrasi ekstrak tanaman serai (Cymbopogon citratus) maka akan semakin 
memiliki pengaruh sebagai larvisida terhadap Aedes sp. WHO menyebutkan bahwa konsentrasi larvasida dianggap efektif apabila menyebabkan kematian larva antara $10 \%-95 \%$. Sedangkan perbandingan antara konsentrasi uji 5\% dengan 10\%, $10 \%$ dengan $15 \%$, dan $5 \%$ dengan $15 \%$, dapat disimpulkan bahwa tidak ada perbedaaan yang bermakna $(\mathrm{p} \geq 0,05)$ atau dapat dikatakan kedua konsentrasi tersebut memiliki daya bunuh yang sama. ${ }^{17}$

Pada akhir penelitian yaitu jam ke-24, uji analisis probit diketahui $\mathrm{LC}_{50}$ dan $\mathrm{LC}_{90}$ secara berturut-turut adalah $11,01 \%$ dan 22,80\% (Tabel 5). Hasil tersebut berarti dibutuhkan konsentrasi sebesar 11,01\% untuk membunuh setengah populasi larva pada jam ke-24 dan 22,80\% untuk membunuh $90 \%$ larva pada jam ke- 24 . Pada beberapa penelitian terdapat perbedaan konsentrasi letal. Perbedaan ini terjadi karena pada beberapa penelitian yang telah terjadi memiliki sampel larutan penguji tanaman serai yang didapat dari proses pembuatan ekstrak atau konsentrasi yang berbeda. Pada penelitian ini sampel dilarutkan dengan aquades dengan berbagai konsentrasi sebagai larvasida alami. Belum diketahui dengan pasti alasan perbedaan metode ekstraksi dapat mempengaruhi $\mathrm{LC}_{50}$ dan $\mathrm{LC}_{90}$ namun beberapa penelitian lainnya mendukung akan hal ini.

Uji analisis probit untuk menilai LT tercantum pada tabel 6. Diketahui $\mathrm{LT}_{50}$ pada konsentrasi $5 \%, 10 \%, 15 \%, 20 \%$ dan kontrol secara berturut-turut adalah 50,0 jam, 40,4 jam, 27,4 jam, -1,6 jam, dan 141,5 jam. Kemudian nilai LT $_{55}$ pada konsentrasi 20\% sebesar 2,5 jam. Hasil ini berarti pada konsentrasi $20 \%$ dibutuhkan waktu 2,5 jam agar $55 \%$ populasi larva dapat mati, konsentrasi 5\% dibutuhkan waktu 50 jam agar separuh populasi larva dapat mati, begitu pula untuk konsentrasi yang lain. Sedangkan dan $\mathrm{LT}_{90}$ pada konsentrasi 5\%, 10\%, 15\%, 20\% dan kontrol secara berturut-turut adalah 92.2 jam, 82.6 jam, 69.6 jam, 40.5 jam, dan 183.6 jam. Hasil tersebut menunjukan bahwa pada konsentrasi 5\% dibutuhkan waktu 92.2 jam untuk membunuh $90 \%$ populasi larva, dan pada konsentrasi $20 \%$ membutuhkan 40.5 jam untuk membunuh 90\% larva. Pada beberapa penelitian terdapat perbedaan waktu letal.

Ekstrak larvasida alami ini dengan konsentrasi $20 \%$ dinyatakan efektif mematikan larva Aedes sp. selama 24 jam observasi. Rata-rata kematian larva nyamuk mengalami peningkatan pada masingmasing konsentrasi yang dinaikkan atau ditingkatkan. Ekstrak larvasida alami yang bersifat toksik ini mengalami kontak langsung dengan larva nyamuk sehingga masuk dalam tubuh larva, dimana hal ini sejalan dengan penelitian yang dilakukan di Jombang pada tahun 2018. ${ }^{17,20}$

Efek toksik yang ditimbulkan dari larvasida alami ini terlihat dari pergerakan atau gejala dari larva Aedes sp. saat kontak dengan ekstrak tanaman serai yaitu gerakannnya menjadi lambat dengan posisi menggantung dan akhirnya mati seiring dengan penambahan konsentrasi murni. Hal tersebut mengindikasikan bahwa larva telah kehabisan energi, dan keadaan ini sejalan dengan mekanisme senyawa bioaktif serta kandungan kimia tanaman serai yang paling besar seperti sitronelal dan geraniol. ${ }^{20}$ Pada tahun 2020 di Gorontalo, Yatuu dkk juga melakukan penelitian yang sama mengenai pengaruh perasan daun serai dapur (Cymbopogon citratus) dengan konsentrasi $15 \%$, 30\% dan $45 \%$ masingmasing perlakuan diberikan 15 ekor larva yang diamati selama 1x24 jam didapatkan hasil kematian larva terendah pada konsentrasi $15 \%$ dan kematian tertinggi pada konsentrasi 20\%. Dapat dikatakan bahwa perasan daun serai dapur (Cymbopogon citratus) memiliki efek terhadap kematian larva Aedes $s p .^{12}$ Pradani dkk melakukan percobaan pada tahun 2017 mengenai daya proteksi serai dapur (Cymbopogon citratus) terhadap nyamuk Aedes aegypti pada konsentrasi $1 \%, 3 \%, 6 \%$, dan 9\%. Didapatkan hasil dimana tanaman serai dapur ini efektif dalam membasmi nyamuk Aedes aegypti. ${ }^{21}$ Tanaman serai merupakan tanaman asli Indonesia dengan ketersediaan yang melimpah ini diketahui mengandung 
senyawa aktif seperti sitronelal, sitronelol, dan geraniol. Hal ini diteliti oleh Willy Tirza Eden dkk di Semarang tahun 2020, yang diidentifikasi pada menit ke 13.6, 16.6, dan 18.6 menit dan didapatkan hasil ketiga komponen aktif ini ampuh membasmi Aedes $s p .^{22}$

\section{SIMPULAN}

Ekstrak tanaman serai (Cymbopogon citratus) ampuh dalam mematikan larva nyamuk Aedes sp. seiring dengan ditingkatkan konsentrasi pada tiap perlakuan, dengan konsentrasi yang paling ampuh atau efektif dalam membunuh larva Aedes sp. ialah konsentrasi $20 \%$.

\section{Konflik Kepentingan}

Penulis menyatakan tidak terdapat konflik kepentingan dalam studi ini.

\section{DAFTAR PUSTAKA}

1. Gesriantuti N, Badrun Y, Fadillah Gesriantuti, Novia, Badrun, Yeeri, Fadillah. Komposisi dan Distribusi Larva Nyamuk Aedes pada Daerah Endemis Demam Berdarah Dengue di Kota Pekanbaru. Jurnal Sains dan Kesehatan 2017;8(1): 105-14.

2. WHO. Comprehensive Guidelines for Prevention and Control of Dengue and Dengue Haemorrhagic Fever [Internet]. WHO Regional Publication SEARO. 2011. 159168p. Available from: http://scholar.google.com/scholar? $\mathrm{hl}=$ en \&btnG=Search\&q=intitle:Co mprehensive+Guidelines+for+Pre vention+and+Control+of+Dengue + and + Dengue + Haemorrhagic $+F e v$ er\#13. H B. Biology and Role of Aedes albopictus (Skuse) 1894 as Vector of Diseases. Aspirator $\mathrm{J}$ Vector Borne Dis Stud. 2011;3(2):117-25.

3. Boesri H. Biologi dan Peranan Aedes albopictus (Skuse) 1894 sebagai Penular Penyakit. Aspirator. 2011; 3(2):117-25.
4. Agustin I, Tarwotjo U, Rahadian R.. Perilaku Bertelur Dan Siklus Hidup Aedes Aegypti Pada Berbagai Media Air. Jurnal Biologi.2017;6(4):71-81.

5. Sutanto I, Ismid IS, Sjarifuddin PK, Sungkar S. Buku Ajar Parasitologi Kedokteran Edisi Keempat. Jakarta: Balai Penerbit UI, 2009.

6. Ridha MR, Fadilly A, Rosvita NA. Nocturnal activity of Aedes (Stegomyia) aegypti and Ae. (Stg) albopictus (Diptera: culicidae) in several area in Kalimantan. Journal Health Epidemiology 2018;3(2):50-5.

7. Ginanjar D. Demam Berdarah. Yogyakarta: B-first, 2008.

8. Khabbaz RF, Ostroff SM, LeDUC JW, Moseley R, Hughes JM. Emerging and Reemerging Infectious Disease Threats [Internet]. Ninth Edition. Mandell, Douglas, and Bennett's Principles and Practice of Infectious Diseases. Philadelphia: Elsevier Inc.; 2010. 199-219 p. Available from: https://doi.org/10.1016/B978-0323-48255-4.00014-X

9. Guzman MG, Harris E. Dengue. Lancet. 2015;385(9966):453-65.

10. Bhatt L, Kale RD. Lemongrass (Cymbopogon Flexuosus Steud.) wats treated textile: A control measure against vector-borne diseases. Heliyon. 2019;5:1-10.

11. Husna Zulkrnin NS, Rozhan NN, Zulkfili NA, Nik Yusoff NR, Rasat MSM, Abdullah NH, et al. Larvicidal Effectiveness of Azolla pinnata Against Aedes aegypti (Diptera: Culicidae) with Its Effects on Larval Morphology and Visualization of Behavioural Response. Journal of Parasitology Research. 2018; 2018:1-5.

12. Yatuu US, Jusuf $\mathrm{H}$, Lalu NAS. Pengaruh perasan daun serai dapur (Cymbopogon citratus) terhadapa kematian larva Aedes aegypti. 
Jambura J Heal Sci Res. 2020; 2(1):32-42.

13. Manh HD, Hue DT, Hieu NTT, Tuyen DTT, Tuyet OT. The Mosquito Larvicidal Activity of Essential Oils From Cymbopogon and Eucalyptus Species in Vietnam. Insects. 2020;11(2):1-7.

14. Kawiji K, Khasanah LU, Pramani CA.Pengaruh Perlakuan Awal Bahan baku dan Waktu Destilasi Serai Dapur Terhadap Karakteristik Fisikokimia Minyak Serai Dapur (Lemongrass oil). Jurnal Teknologi Hasil Pertanian. 2010;3:59-71.

15. Avoseh O, Oyedeji O, Rungqu P, NkehChungag B, Oyedeji A. Cymbopogon species; Ethnopharmacology, Phytochemistry and Pharmacological Importance. Molecules. 2015;20(5):7438-53.

16. Eid Abdelmagyd HA, Ram Shetty DS, Musa Musleh Al-Ahmari DM. Herbal medicine as adjunct in periodontal therapies- A review of clinical trials in past decade. Journal of Oral Biology and Craniofacial Research [Internet]. 2019;9(3):212-7. Available from: https://doi.org/10.1016/j.jobcr.201 9.05.001

17. Kusumawati WD, Subagiyo A, Firdaust M. Pengaruh Beberapa Dosis dan Jenis Ekstrak Larvasida Alami Terhadap Kematian Larva
Nyamuk Aedes aegypti. Buletin Keslingmas. 2018;37(3):283-95.

18. Mangelep DNO. Efektivitas Sari Batang Serai Dapur (Cymbopogon citratus) Sebagai Larvasida Aedes sp. [Skripsi]. Kendari: Poltekes Kemenkes Kendari, 2018.

19. Wulan S, Setyawati T, Towidjojo V., Wahyuni R. Uji Efektivitas Larvasida Ekstrak Daun Mahkota Dewa (Phleria macrocarpa) Terhadap Larva Nyamuk Aedes aegypti Instar III. Jurnal Ilmiah Kedokteran. 2018;5(3):1-11.

20. Merisia, Farhan A, Umaysaroh. Uji Ekstrak Batang Sereh (Cimbopogon nardus L Rendle) dalam membunuh Larva Aedes aegypti (Studi di Laboratorium Parasitologi). [Karya Tulis Ilmiah]. Jombang: STIKES Insan Cendekia Medika, 2018

21. Pradani FY, Nurindra RW. Daya Proteksi Serai Dapur (Cymbopogon citratus) Terhadap Nyamuk Aedes aegypti. Spirakel. 2017; $9(2): 60-7$.

22. Eden WT, Alighiri D, Supardi KI, Cahyono E. The Mosquito Repellent Activity of the Active Component of Air Freshener Gel from Java Citronella Oil (Cymbopogon winterianus). Journal of Parasitology Research 2020;2020: $1-5$. 